\title{
Influence of Nitrogen Levels and Times of Application on Growth Parameters of Aerobic Rice
}

\author{
K. Anil ${ }^{*}$, M. Yakadri ${ }^{2}$ and G. Jayasree ${ }^{3}$ \\ ${ }^{1}$ Department of Agronomy, ${ }^{3}$ Department of Soil Science, College of Agriculture, Acharya N.G. \\ Ranga Agricultural University, Hyderabad, Telangana, India \\ ${ }^{2}$ AICRP on Weed Control, Rajendranagar, Hyderabad, Telangana, India \\ *Corresponding author
}

\section{A B S T R A C T}

\begin{tabular}{|l|}
\hline Ke y w o r d s \\
Nitrogen, growth, \\
aerobic rice
\end{tabular}

\section{Introduction}

Rice is the staple food in Asia but also the single biggest user of freshwater. It is mostly grown under submerged soil conditions and requires more water compared with other crops. Asia's irrigated rice fields consume more than $40 \%$ of the world's freshwater that is used for agriculture (Bouman 2002) [1]. Tuong and Bouman (2003) [2] estimated that, by 2025 , approximately two million hectares of irrigated dry-season rice and 13 million hectares of wet-season rice will experience water scarcity. The declining availability and increasing costs of water threaten the traditional way of producing irrigated rice. Moreover, lack of rainfall is a major production constraint in rain-fed areas where many poor rice farmers live. Under these circumstances, new technologies and methods need to be developed to help farmers cope with water shortages for rice production. Aerobic rice production is a revolutionary way of growing rice in well-drained, non-puddled, and non-saturated soils without ponded water. This system uses input-responsive specialized rice cultivars and complementary management practices to achieve at least 4-6 t/ha using only $50-70 \%$ of the water required for irrigated rice production. This is recommended in areas 
where water is too scarce or expensive to allow traditional irrigated rice cultivation.

The low and unstable yields of aerobic rice were also due to nutrient stresses. Nitrogen fertilization and proper time of its application is the major agronomic practice that affects the yield and quality of rice crop, which requires as much as possible at an early and mid tillering stages to maximize panicle numbers and during reproductive stages to produce more number of spikelets per panicle and percentage filled spikelets (Lampayan et al., 2010) [3]. In aerobic system, the dominant form of nitrogen is nitrate and relatively little ammonia volatilization is expected after fertilizer nitrogen application. The alternate moist and dry soil conditions may stimulate nitrification-denitrification processes in dry sown rice, resulting in a loss of nitrogen through $\mathrm{N}_{2}$ and $\mathrm{N}_{2} \mathrm{O}$ (Prasad, 2011) [4]. The differences in soil $\mathrm{N}$ dynamics and pathways of nitrogen losses in dry sown rice system may result in different fertilizer nitrogen recoveries. With even high nitrogen applications in aerobic rice, grain filling may be limited by a low contribution of postanthesis assimilates (Zhang et al., 2009) [5].

\section{Materials and Methods}

An experiment on "Effect of nitrogen levels and times of application on growth parameters of aerobic rice (Oryza sativa L)" was carried out during kharif 2012 at Agricultural Research institute Rajendranagar. The soil of the experimental site was clay loam and slightly alkaline in reaction $(\mathrm{pH} 7.58)$ with medium organic carbon $(0.54 \%)$ available phosphorus $\left(\mathrm{P}_{2} \mathrm{O}_{5} 46.0 \mathrm{~kg} \mathrm{ha}{ }^{-1}\right)$, available potassium (283 kg ha-1) and low in available in nitrogen $\left(151 \mathrm{~kg} \mathrm{ha}^{-1}\right)$. The experiment was laid out in randomized block design (factorial concept) with three nitrogen levels viz., 120 $\left(\mathrm{N}_{1}\right), 180\left(\mathrm{~N}_{2}\right)$ and $240 \mathrm{~kg} \mathrm{ha}^{-1}\left(\mathrm{~N}_{3}\right)$ and three (3, 4 and 5) splits of applications replicated thrice. The test variety grown was MTU-1010 (Cotton Dora Sannalu) of medium slender grain type with duration of 110-125 days.

\section{Results and Discussion}

Different nitrogen levels significantly influenced the height of the rice plant, Application of nitrogen @ $240 \mathrm{~kg} \mathrm{ha}{ }^{-1}$ recorded significantly taller plants at 30,60, $90 \mathrm{DAE}$ and at harvest over $120 \mathrm{~kg}$ but was at par with that of $180 \mathrm{~kg}$ only at 30 and 60 DAE, but was on par at 90 DAE, and at harvest. Nitrogen is associated with protoplasm synthesis and vigorous vegetative growth due to increased cell division and cell elongation. Hence, application of nitrogen resulted in the significant increase in plant height at early stage of crop growth (Latheef, 2010 [6], Malla Reddy et al., 2012 [7] and Sandya Rani, 2012 [8]).

Among the time of application, 4 equal splits $\left(\mathrm{T}_{2}\right)$ resulted in significantly taller plants over $3\left(\mathrm{~T}_{1}\right)$ or 5 splits $\left(\mathrm{T}_{3}\right)$.

The interaction effect of nitrogen levels and time of application on plant height of aerobic rice at 30,60, 90 and at harvest was found to be statistically significant. Among the different treatment combinations, $\mathrm{N}_{2} \mathrm{~T}_{2}$ i.e. application of nitrogen @ $180 \mathrm{~kg} \mathrm{ha}^{-1}$ with 4 equal splits significantly enhanced the plant height compared to the remaining treatment combination.

Even higher dose $\left(240 \mathrm{~kg} \mathrm{~N} \mathrm{ha}^{-1}\right)$ at 3 splits or 4 splits or even 5 splits proved inferiority compared to $180 \mathrm{~kg} \mathrm{~N}$ at 4 splits, indicating less splits $\left(\mathrm{T}_{1}\right)$ might have encouraged the nitrogen loss in various ways and too many splits $\left(\mathrm{T}_{3}\right)$ could not have delivered the required quantity of nitrogen at various phenological stages of rice plants. The similar findings were also reported by Devi and Sumathi (2011) [9] (Table 1). 
Table.1 Growth parameters of aerobic rice as influenced by nitrogen levels and times of application

\begin{tabular}{|c|c|c|c|c|c|c|c|c|c|c|c|c|c|c|}
\hline \multirow[t]{2}{*}{ Treatment } & \multicolumn{4}{|c|}{ Plant height (cm) } & \multicolumn{4}{|c|}{ Tiller number $\mathrm{m}^{-2}$} & \multicolumn{4}{|c|}{ Dry matter production $\left(\mathrm{g} \mathrm{m}^{-2}\right)$} & \multirow{2}{*}{$\begin{array}{c}\text { Root } \\
\text { volume } \\
(\text { ce } \\
\left.\text { plant }^{-1}\right) \\
\end{array}$} & \multirow{2}{*}{$\begin{array}{l}\text { Root dry } \\
\text { weight (g } \\
\left.\text { hill }^{-1}\right)\end{array}$} \\
\hline & 30 & 60 & 90 & Harvest & 30 & 60 & 90 & Harvest & 30 & 60 & 90 & Harvest & & \\
\hline \multicolumn{15}{|c|}{ Nitrogen level $\left(\mathrm{kg} \mathrm{N} \mathrm{ha}^{-1}\right)$} \\
\hline $\mathrm{N}_{1}: 120$ & 15.2 & 41.9 & 56.2 & 64.5 & 225.8 & 275.6 & 257.5 & 246.3 & 52.9 & 423.6 & 763.6 & 1352.5 & 19.3 & 9.0 \\
\hline $\mathrm{N}_{2}: 180$ & 16.5 & 47.4 & 59.7 & 70.8 & 238.7 & 301.4 & 286.7 & 275.6 & 62.2 & 533.3 & 880.8 & 1388.1 & 21.6 & 11.6 \\
\hline$N_{3}: 240$ & 16.9 & 48.3 & 60.0 & 71.6 & 239.2 & 301.6 & 287.3 & 276.0 & 62.3 & 534.2 & 881.0 & 1389.5 & 21.8 & 12.3 \\
\hline SEm \pm & 0.1 & 0.4 & 0.1 & 0.1 & 1.3 & 3.6 & 2.5 & 5.4 & 1.6 & 5.0 & 5.9 & 3.7 & 0.43 & 0.28 \\
\hline $\mathrm{CD}(\mathrm{P}=0.05)$ & 0.5 & 1.2 & 0.3 & 0.5 & 4.0 & 11.0 & 7.5 & 16.3 & 4.9 & 15.1 & 17.8 & 11.1 & 1.29 & 0.84 \\
\hline \multicolumn{15}{|c|}{ Time of Application (T) } \\
\hline $\begin{array}{l}T_{1}: 3 \text { equal splits at } \\
\text { basal, } 30 \text { and } 60 \\
\text { DAE }\end{array}$ & 15.7 & 44.0 & 56.0 & 65.1 & 228.2 & 283.6 & 267.2 & 256.3 & 57.6 & 475.9 & 805.7 & 1306.2 & 19.0 & 10.1 \\
\hline $\begin{array}{l}\mathrm{T}_{2}: 4 \text { equal splits at } \\
\text { basal, } 20,40 \text { and } \\
60 D A E\end{array}$ & 16.9 & 48.0 & 61.5 & 72.9 & 239.2 & 298.7 & 285.7 & 274.6 & 60.9 & 521.5 & 869.7 & 1430.9 & 23.0 & 12.0 \\
\hline $\begin{array}{l}\text { T}_{3}: 5 \text { equal splits at } \\
\text { basal, } 15,30,45, \\
\text { and } 60 \mathrm{DAE}\end{array}$ & 16.0 & 45.6 & 58.4 & 68.8 & 236.4 & 296.3 & 278.6 & 267.0 & 58.9 & 493.6 & 850.0 & 1393.0 & 20.8 & 10.9 \\
\hline SEm \pm & 0.1 & 0.4 & 0.1 & 0.1 & 1.3 & 3.6 & 2.5 & 5.4 & 1.6 & 5.0 & 5.9 & 3.7 & 0.43 & 0.28 \\
\hline $\mathrm{CD}(\mathrm{P}=0.05)$ & 0.5 & 1.2 & 0.3 & 0.5 & 4.0 & 11.0 & 7.5 & 16.3 & NS & 15.1 & 17.8 & 11.1 & 1.29 & 0.84 \\
\hline \multicolumn{15}{|l|}{ Interaction $(\mathbf{N} \times \mathbf{T})$} \\
\hline SEm \pm & 0.3 & 0.7 & 0.2 & 0.3 & 2.3 & 6.3 & 4.3 & 9.4 & 2.8 & 8.7 & 10.3 & 6.4 & 0.74 & 0.48 \\
\hline $\operatorname{cd}(p=0.05)$ & 1.0 & 2.1 & 0.6 & 1.0 & 7.1 & 19.1 & 13.0 & 28.3 & 8.6 & 26.2 & 30.9 & 19.3 & 2.24 & 1.46 \\
\hline
\end{tabular}


Different levels of nitrogen significantly influenced the tiller number of aerobic rice. Application of $240 \mathrm{~kg} \mathrm{~N} \mathrm{ha}{ }^{-1}\left(\mathrm{~N}_{3}\right)$ caused significant increase in the number of tillers $\mathrm{m}$ ${ }^{2}$ over $120 \mathrm{~kg} \mathrm{ha}^{-1}\left(\mathrm{~N}_{1}\right)$ but it was on par with $180 \mathrm{~kg} \mathrm{ha}^{-1}\left(\mathrm{~N}_{2}\right)$ at all the stages of crop growth. This was mainly due to more nitrogen availability at higher levels of nitrogen that provided proper nutrition to the crop thereby increased tillering. These findings are in accordance with the reports of Sathiya et al., (2008) [10], Sandya Rani (2012) [8] and Malla Reddy et al., (2012) [7].

Schedule of nitrogen application in 4 splits $\left(\mathrm{T}_{2}\right)$ recorded significantly more number of tillers $\mathrm{m}^{-}$ 2 at 30, 60, 90 DAE, and at harvest over 3 splits $\left(\mathrm{T}_{1}\right)$ and 5 splits $\left(\mathrm{T}_{3}\right)$. Application of optimum nitrogen within the time interval of 20 days during grand vegetative stage might have induced the more number of tillers $\mathrm{m}^{-2}$ as observed by the Devi and Sumathi (2011) [9].

The interaction effect of nitrogen levels and time of application on tiller number $\mathrm{m}^{-2}$ in aerobic rice at various stages was found to be statistically significant. Among the different treatment combinations, $\mathrm{N}_{2} \mathrm{~T}_{2}$ i.e. $180 \mathrm{~kg} \mathrm{~N}$ at 4 splits generated significantly more tillers compared to rest of the treatment combinations at various stages. With lower $\left(120 \mathrm{~kg} \mathrm{ha}^{-1}\right)$ or higher dose $\left(240 \mathrm{~kg} \mathrm{ha}^{-1}\right)$ of nitrogen, either at one month interval (3splits) or 15 days interval (5splits) proved to be inferior in inducing the more tillers in aerobic rice and these results are in conformity with Devi and Sumathi (2011) [9].

The dry matter production increased significantly with successive increment of $60 \mathrm{~kg}$ $\mathrm{N} \mathrm{ha}^{-1}$ from 120 to $240 \mathrm{~kg} \mathrm{ha}^{-1}$ at all the crop growth stages. Dry matter produced with $180 \mathrm{~kg}$ $\mathrm{N} \mathrm{ha}^{-1}$ were at par with $240 \mathrm{~kg}$ at all the growth stages. Higher dose of nitrogen might have helped in inducing vegetative growth leading to better interception of photosynthetically active radiation and greater photosynthesis by the crop. These results are in conformity with the findings of Shekara et al., (2010) [11], Sandya
Rani (2012) [8] and Malla Reddy et al., (2012) [7].

As far as split application is concerned, application of nitrogen in 4 splits $\left(\mathrm{T}_{2}\right)$ recorded significantly more dry matter production at 60 , $90 \mathrm{DAE}$ and at harvest over 3 splits $\left(\mathrm{T}_{1}\right)$ and 5 splits $\left(\mathrm{T}_{3}\right)$. This may be due to application of nitrogen in 4 splits where the crop was supplied with required levels of $\mathrm{N}$ at critical periods and induced the more tillers and thereby dry matter production.

The interaction effect of nitrogen levels and time of application on dry matter production at 30, 60, 90 DAE and at harvest was statistically significant. Among the different treatment combinations, $\mathrm{N}_{2} \mathrm{~T}_{2}$ (180 kg N with 4 splits) recorded significantly highest dry matter compared to remaining treatment combinations at all the growth stages. Because aerobic rice responded well to increased nitrogen levels from $120 \mathrm{~kg}$ to $180 \mathrm{~kg} \mathrm{~N}$ as the available soil nitrogen was low and this quantity when applied in 4 equal splits might have utilized well giving minimum scope to various nitrogen losses under aerobic conditions as is evidenced by its vigorous root development (more root volume and dry weight). The overall impact of this has been reflected in enhanced plant height, swelled tiller number that contributed to more dry matter production. These findings are in conformity with that of Devi and Sumathi (2011) [9] and Lampayan et al., (2010) [3].

Highest root volume and dry weight $(21.8 \mathrm{cc}$ plant ${ }^{-1}$ and $12.3 \mathrm{~g} \mathrm{hill}{ }^{-1}$ ) was recorded with application of $240 \mathrm{~kg} \mathrm{~N}^{-1}$ which is on par with $180 \mathrm{~kg} \mathrm{~N} \mathrm{ha}^{-1}\left(21.6 \mathrm{cc}^{\mathrm{c}} \mathrm{plant}^{-1}\right.$ and $11.6 \mathrm{~g}$ hil $^{-1}$ ) and significantly superior to $120 \mathrm{~kg} \mathrm{~N} \mathrm{ha}^{-1}$ (19.3cc plant ${ }^{-1}$ and 9.0g hill ${ }^{-1}$ ). Applications of higher $\mathrm{N}$ (240 and $180 \mathrm{~kg} \mathrm{~N} \mathrm{ha}{ }^{-1}$ ) have produced more dry matter that could produce additional photosynthates for the development of root system. This was reflected in increased root volume and dry weight. These findings are in agreement with the reports of Maheswari et al., (2007) [12]. 
Among the time of application, 4 splits $\left(\mathrm{T}_{2}\right)$ recorded maximum root volume $\left(23.0 \mathrm{cc}^{\mathrm{c}}\right.$ plant $\left.{ }^{1}\right)$ and dry weight $\left(12.0 \mathrm{~g} \mathrm{hill}^{-1}\right)$ over 3 splits $\left(19.0 \mathrm{cc} \mathrm{plant}^{-1}\right.$ and $\left.10.1 \mathrm{~g} \mathrm{hil}^{-1}\right)$ and 5 splits (20.8cc plant ${ }^{-1}$ and $\left.10.9 \mathrm{~g} \mathrm{hil}^{-1}\right)$. The continuous and optimum supply of nitrogen throughout the crop growth period might have increased the root volume and dry weight (Devi and Sumathi, 2011 [9]).

However, the interaction effect clearly showed that the treatment combination $\mathrm{N}_{2} \mathrm{~T}_{2}(180 \mathrm{~kg} \mathrm{~N}$ with 4 splits) recorded more root volume and dry weight that has struck a balance between doses and time of nitrogen application, because of the reason that continuous and optimum supply of nitrogen throughout the crop growth period might have increased the root volume and dry weight.

\section{References}

Bouman B.A.M., Xiaoguang Y., Huaqui W., Zhiming W., Junfang Z., Changgui W. and Bin C. 2002. Aerobic rice (Han Dao): A new way growing rice in water short areas. In: Proceedings of the12th International Soil Conservation Organization Conference. May 26-31. Beijing, China. Tsinghua University. pp. 175-181.

Devi, G and Sumathi, V. 2011. Effect of nitrogen management on growth, yield and quality of scented rice under aerobic conditions. Journal Research ANGRAU. 39(3): 81-83.

Lampayan, R.M., Bouman, B.A.M., Dios, J.L.D., Espirity, A.J., Soriano, J.B., Lactaoen, A.T., Faronilo, J.E and Thant, K.M. 2010. Yield of aerobic rice in rainfed lowlands of the Philippines as affected by nitrogen management and row spacing. Field Crops Research. 116: 165-174.

Latheef Pasha, MD. 2010. Performance of aerobic rice under different levels of irrigation, nitrogen and weed management. M.Sc. (Ag.) Thesis. Acharya N G Ranga Agricultural University, Hyderabad, India.

Maheswari, J., Maragatham, N and Martin, G.J. 2007. Relatively simple irrigation scheduling and $\mathrm{N}$ application enhances the productivity of aerobic rice (Oryza sativa L.) American Journal of Plant Physiology. 2 (4): 261-268

MallaReddy, M., Padmaja, B., Veeranna, G and Reddy, V. 2012.Evaluation of popular kharif rice (Oryza sativa L.) varieties under aerobic condition and their response to nitrogen dose. Journal Research of ANGRAU. 40(4): 14-19.

Prasad, R. 2011. Aerobic rice Systems. Advances in Agronomy. 111: 207-246.

Sandya Rani, K. 2012.Influence of nitrogen and weed management on growth and yield of aerobic rice. M.Sc. (Ag.) Thesis. Acharya N G Ranga Agricultural University, Hyderabad, India.

Sathiya, K., Sathyamoorthi, K and Martin, G.J. 2008.Effect of nitrogen levels and split doses on the productivity of aerobic rice. Research on Crops. 9(3): 527-530

Shekara, B.G., Nagaraju and Shreedhara, D. 2010. Growth and yield of aerobic rice as influenced by different levels of $\mathrm{N}, \mathrm{P}$ and $\mathrm{K}$ in Cauvery command area. Journal of Maharashtra Agricultural Universities. 35 (2): 195-198.

Tuong, T.P and Bouman, B.A.M. 2003. Rice production in water scarce environments. To be published in proceedings of the water productivity workshop, 12-14 Nov.2001, International Water Management Institute, Srilanka.

Zhang, L., Lin, S., Bouman, B.A.M., Xue, C., Wei, F., Tao, H., Yang, H., Wang, D.Z and Dittert, K. 2009. Response of aerobic rice growth and grain yield to $\mathrm{N}$ fertilizer at two contrasting sites near Beijing, China. Field Crops Research. 114: 45-53.

\section{How to cite this article:}

Anil, K., M. Yakadri and Jayasree, G. 2018. Influence of Nitrogen Levels and Times of Application on Growth Parameters of Aerobic Rice. Int.J.Curr.Microbiol.App.Sci. 7(05): 1525-1529. doi: https://doi.org/10.20546/ijcmas.2018.705.179 